\title{
Optimal Indirect Tax Revenues and Economic Growth in Sudan Economy: A Threshold Regression Approach
}

\author{
Khalafalla Ahmed Mohamed Arabi \\ Professor of Econometrics and Social Statistics \\ College of Business, King Khalid University, Saudi Arabia \\ Khalid Hassan Elbeely \\ Professor of Economic, College of Business Studies, \\ Sudan University of Science and Technology, Sudan
}

Doi:10.19044/esj.2019.v15n13p127 URL:http://dx.doi.org/10.19044/esj.2019.v15n13p127

\begin{abstract}
Indirect taxes play a fundamental role in revenue collection in Sudan. This role is under investigation by estimating an optimum level beyond which they make vulnerable the acceleration of economic growth. A threshold regression was used for estimation which covers the period $1970-2017$. The model contains real GDP (Y) as the dependent variable and indirect taxes as a threshold variable. The unemployment rate (UR), the external gap (GAP2), and the real effective exchange rate (REER) are the non-threshold variables. The main research findings indicate that the average indirect tax ratio is more than three times the direct tax ratio and constitutes about $55.3 \%$ of the total revenue collection compared to $18 \%$ of the direct tax. These findings suggest that the optimum threshold is $7.46 \%$ above which indirect taxes exert a negative impact on economic growth. It is clear that resorting to indirect taxes fosters the maximum economic growth at the threshold that corresponds to the year 1982. This year is considered to be the most economically stable year (elected as a base year). Here the non-threshold variables i.e. external gap represents $0.03 \%$ of its mean value, while real exchange rate and employment rate are less than their mean values. This paper focuses on restructuring the tax system which is highly recommended to shift the balance in favor of direct taxes so as to curb price rises, attain social and economic balance, and reduce income inequality. Economic policies have to be focused on tackling unemployment especially among young graduates and disguised unemployment. Here, monitory policy can stimulate demand and put the economy back on track, as well as a fiscal policy through taxation and government spending. A favorable economic environment conducive for investment and jobs creation ought to be one of the priorities. Job description
\end{abstract}


and irradiation of nepotism can help much in reducing unemployment. Export diversification and improved range of merchandized, recapitalization of the export-import (EXIM) bank for smooth credit provision, revision of rules \& tariffs, creation of single window for customs clearance, and the stable exchange rate should be the main concern of the government.

Keywords: Indirect taxes balance, Inflation, Optimum level, Tax structure, The threshold

\section{Introduction}

One of the main functions of fiscal policy is to stabilize and consolidate the process of economic performance to support economic growth. Financing public projects require the mobilization of internal and external resources. The standard theory of optimal taxation suggests that the choice of a tax system is to maximize a social welfare function subject to a set of constraints (Mankiw, Weinzierl \& Yagan 2007). A well-structured, efficient and successful tax system is an essential precondition for economic growth (Ahmad, Sial \& Ahmad 2018). Taxation can affect growth through its impact on physical capital, human capital, and through its effect on the total factor productivity (Stoilova \& Patonov, 2013). Usually, governments rely on indirect taxes on the assumption that individuals and corporations would endure fewer burdens, thus forming a favorable climate for domestic saving and foreign investment. However, continuous reliance on direct taxes has a negative influence on economic growth (Phiri 2016). Consecutive Sudanese governments since independence in 1956 have been relying greatly on indirect taxes as a major source of revenue. The maximum indirect tax ratio to GDP is $13.4 \%$ compared to $11.4 \%$ of the direct taxes ratio. Sudan continued to depend on indirect tax, whereas the tax on domestic and international trade accounted for over $70 \%$ of the total revenue and over 90\% of tax revenue remained in 2016-2017. Alternatively, a direct tax on income, profits, and capital gains and the property remained minor; and accounted for around $9 \%$ of the tax revenue during the same period (World Bank, 2017.). Indirect taxes ratio in Sudan correlates negatively to economic growth with significant correlation coefficient -0.34 , which contradicts the finding of Jaimovich and Rebelo (2015). On the other hand, the direct taxes ratio to GDP has an insignificant negative correlation with economic growth.

Sudan economic growth has many factors affecting its magnitude and direction of which may include private consumption and investment and indirect tax revenue through these variables. The effect of indirect taxes on economic growth differs according to their type and rate. Commodity taxation, capital tax, income tax, flattened tax schedule, progressive tax schedule, and the lump-sum tax falls equally on rich and poor and the relative burden on 
poor is greater (Heyman, 2011). Public expenditure depends mainly on taxes. A reduction in tax collection leads to a reduction in government spending, ultimately at the expense of spending on social services, especially health and education, water, and other critically needed goods and services (Medani, \& Bell 2004).

The motivation for this research is that the literature addressing the issue in the context of the Sudan economy is sparse. To the best of our knowledge, there are only two Ph.D. students working on estimating an optimal level of external debt and public expenditure that affect Sudanese economic growth. This is besides the desire to bring new empirical insight into the topic. The core objective of this research is to estimate the optimal level of indirect taxes that fosters economic growth in Sudan. The research problem can be summed up in the following main research question: what is the optimal level of indirect taxes that foster economic growth? We hypothesize that those indirect taxes - despite its negative relationship with economic growth- can accelerate economic growth below a certain threshold.

The structure of the rest of this paper is as follows: section 2 presents related literature. section 3 devoted to the theoretical background; section 4 contains research methodology and data; section 5 discusses empirical results and section 6 concludes the research.

\section{Literature Review}

Our approach to the analysis of previous studies is to categorize them into theoretical studies, empirical studies based on linear estimation models, and studies (Bai \& Perron 1998; Gibson 2011; Chong \& Yan 2014; Jaimovich \& Rebelo, 2015; Iyidogan \&Turan 2017) that used non-linear approaches.

The observed nonlinearities in economic and financial data led to the introduction of regime switching models. The growing interest in nonlinear models shifted the attention towards the development of threshold regression models. Gibson (2011) introduced threshold autoregressive (TAR) where observable variable, $\mathbf{q}_{\mathbf{t}}$ determines the regime at time $\mathbf{t}$ relative to a threshold. When this observable variable is the dependent variable, the model becomes Self-Exciting TAR (SETAR) and uses sequential least squares for estimation. Bai, and Perron, (1998) replicated the general case of a partial structural change model where not all parameters are subject to shifts and proposed a procedure that allows one to test the null hypothesis of, L changes, versus the alternative hypothesis of $\mathrm{L}+1$ changes and a systematic modeling cycle approach for smooth threshold autoregressive (STAR) models. Chong and Yan (2014) provided the theoretical foundation for threshold models with multiple threshold variables. Jaimovich and Rebelo, (2015) proposed a threshold model consistent with two observations. Terârasvirta (1994) tested the linearity against parametric alternatives. 
Various econometric models empirically investigated the role of taxes on accelerating economic growth. Some engaged in the issue by estimating the magnitude of this effect as well as the direction of the relation by utilizing multiple linear regressions as stated by Stoilova and Patonov (2013). However, this was done by using regression analysis to investigate tax burden in the EU member states during the 1995 - 2010. They concluded that direct taxes are more efficient in supporting economic growth. Ilaboya and Mgbame (2012) examined the tax-economic growth dynamic in Nigeria through ARDL to find an insignificant negative relationship between economic growths. Morau and Ioniţă (2014) tested the relationship between revenue and Romanian growth by linear regression using distortionary which includes income, wage, and social security contribution; and nondistortionary direct taxes and indirect taxes. Quarterly data from 2006 - 2013 have been subjected to seasonal adjustment. They found that the coefficient of distortionary is onequarter of nondistortionary. Ribo (2016) estimated the impact of personal income tax, corporate income tax, and value added tax on growth via autoregressive distributed lags (ARDL) model for South Africa. Others worked with vector error correction models Chudik et.al. (2015) investigated the long-run impact of public debt expansion on economic growth and whether the debt-growth relation varies with the level of indebtedness. Ahmad, Sail, and Ahmad (2018) investigated the empirical relationship between indirect taxes and economic growth in Pakistan. For estimation, the annual time series data (1974 - 2010) has been used through ARDL. Due to a one percent increase in indirect taxes, economic growth would decrease by $1.68 \%$. ECM coefficient of indirect taxes shows $45 \%$ speed of adjustment in a year

A bit different approach was followed by Loganathan et.al. (2017) exploring the dynamic linkage between financial development, inflation and economic growth on tax revenue condition for Malaysia. They used the Cointegration test with various structural breaks, bootstrap rolling window causality applications to capture the U-shape condition of tax-led-growth. They established that there is unidirectional causality running between taxation with financial development and inflation, and there is a unidirectional causality running from GDP to taxation Bâzagan (2018) was setting up a positive impact of indirect taxes on economic growth in Romania, while direct taxes have a significant influence on growth negatively in the next period of their implementation. Hunady and Oraviska (2015) used panel fixed effects model for EU member states covering the period 1999 - 2011 and thet estimated an optimal level of the corporate tax rate that maximizes economic growth in the average EU growth.

Samimi; Nademi, and Zobeiri (2010) estimated the rate and effect of threshold tax on economic growth in Iran during 1980 - 2008 via the nonlinear model. Results indicate that there exists a threshold tax of $22 \%$. Baum, Anja, 
and Koester (2011) analyzed quarterly German data from 1976 to 2009 in a threshold SVAR. By expanding the SVAR approach, they found that hiking spending yields a short-term fiscal multiplier of around 0.70 , while the fiscal multiplier resulting from an increase in taxes and social security contributions is -0.66. Saibu (2015) examined optimal tax burden and real output growth in Nigeria and South Africa. He calculated the growth-maximizing tax rate as equal to be $15 \%$ of per capita GDP for South Africa and $30 \%$ for Nigeria. Pereiro and Rozada (2015) introduced the SETAR of threshold models into portfolio management, corporate valuation, and the long-term forecasting of financial indicators. Tax on ability distorts incentives exert more effort to earn income (income and effort should be taken together). The government experience tradeoff between equality and efficiency. Moraru and Ioniţă (2014) tested the influence of public revenue in Romania. Iyidgan, Gaspar, Jaramillo and Wingender (2016) performed a study on 139 countries, Iyidogan and Turan (2017) found threshold level for government, private, and investment expenditure in Turkey as a percentage of GDP, and they are 16.5, 12.6, and 3.9 respectively. Esen and Aydin (2018) estimated a threshold using data from 11 Central and Southeastern European and Baltic countries to be $18 \%$ for full transition economies, $18.5 \%$ for developing economies, and $23 \%$ for developed economies.

\section{Theoretical Background}

Economic growth depends mainly on economic factors, usually factor of production which is land and underground resources, human capital in terms of active population and investment in human capital, manufactured capital (capital formation), and technological advancement. Aggregate demand, saving and investment, efficiency of the financial system and fiscal policies and foreign direct investment (know-how and new technology) are additional influential factors on growth (Boldeanu \& Constantinescu, 2015). Rodrik (2000) stated that five kinds of institutional frameworks (property rights, regulatory institutions, institutions for macroeconomic stabilization, institutions for social insurance and institutions of conflict management) could have a direct outcome on growth and on other determinants of economic growth. However, noneconomic factors have a role in economic growth as a political and administrative system, society norms, believe geography and demography (Acemoglu, 2009).

Investment, public expenditure, employment rate, and exchange rate have a different influence on economic growth (Boldeanu \& Constatinescu, 2015). Negative effects of taxes may come from the attitude of individuals and firms. An increase in taxes reduces investment returns and incentives causing a decline in economic growth. On the other hand, taxes revenue assist the 
government to spend on ordinary and development projects boosting the rate of economic growth (Samimi, Nademi, and Zobeiri, 2010).

The value of goods and services sacrificed by the taxpayer is the real cost of government goods and services. Taxation reduces the ability of the taxpayer to acquisitions of goods and services for his own use. Taxes distort choices, affects prices of goods and services, the incentive to work, save and allocate expenditure among goods and services. Taxes impair the operation of the economy by replacing their advantages and disadvantages instead of cost and benefits. Reduced savings and a disincentive to work often leads to loss of output and distortion of resources. The rational use of resources obtained by the government provides goods and services shared by all without a willingness to pay and are not rationed by prices (Heyman, 2011). Taxation of consumption can be used to encourage saving. The areas of tax analysis are marginal tax rate schedule: distribution of ability, decline at high incomes; flat tax, wage inequality, personal characteristic and income, final good, increased sophistication, and taxpayer.

\section{Methodology and Data}

The model contains five variables i.e. real GDP (Y) in million Sudanese pounds, indirect tax revenue ratio to GDP (ITR), unemployment rate (UR), a real effective exchange rate (REER) and the external gap (GAP2). The main source was the Central Bureau of Statistics, the Central Bank of Sudan $(\mathrm{CBoS})$ and the World Bank. The threshold regression model is the main tool of estimation of indirect optimal level.

The threshold analyzes economic variables possessing step-like time paths. The dependent does not move until the concerted action of the independent variables and the error terms induce it to overcome its reaction threshold (Dagenais 1969). The slopes of the threshold regression models vary according to the "regime" switching mechanism that depends on a threshold variable (Hulin 2018). The model is as follows:

$$
y_{t}=\alpha+\beta_{0}^{\prime} x_{t}+\beta_{1}^{\prime} x_{t} h\left(q_{t} ; \theta\right)+\varepsilon_{t}(1)
$$

Where $\boldsymbol{\beta}_{\mathbf{0}}$ and $\boldsymbol{\beta}_{\mathbf{1}}$ are $\boldsymbol{K} \times \mathbf{1}$ vectors, is $\boldsymbol{q}_{\boldsymbol{t}}$ is a threshold variable, $\boldsymbol{\theta}$ is a vector of parameters and $\boldsymbol{h}\left(\boldsymbol{q}_{\boldsymbol{t}} ; \boldsymbol{\theta}\right)$ is a transition function if it is binary then:

$$
\begin{gathered}
h\left(q_{t} ; c\right)=\left\{\begin{array}{l}
1 \text { if } q_{t} \geq c \\
0 \text { if } q_{t}<c
\end{array}\right. \\
y_{t}=\left\{\begin{array}{c}
\alpha+\left(\beta_{0}^{\prime}+\beta_{1}^{\prime}\right) x_{t}+\varepsilon_{t} \text { if } q_{t} \geq c \\
\alpha+\beta_{0}^{\prime} x_{t}+\varepsilon_{t} \text { if } q_{t}<c
\end{array}\right.
\end{gathered}
$$

When we have two regimes for the slope parameters $\left(\beta_{0}\right.$ and $\left.\beta_{0}+\beta_{1}\right)$ we use the following logistic transition function: 


$$
h\left(q_{t} ; \gamma, c\right)=\frac{1}{1+\exp \left(-\gamma\left(q_{t} ; c\right)\right)^{\prime}} ; \gamma>0(4)
$$

The proposed model includes real GDP as the dependent variable explained by foreign saving i.e. export minus import (GAP2), public investment ratio to GDP (DVR), and indirect taxes ratio to GPD (ITR). Indirect taxes and public investment are the threshold variables.

\section{Empirical Results and Discussion}

\subsection{Empirical Results}

The sample period commences in 1970 which is the first year of the military government that lasted for 16 years. Indirect ratio to GDP is nearly $10 \%$ compared to $3.7 \%$ during the next five years of democratic rule, and $4.1 \%$ throughout the current military government which has been ruling since 1990 . The three governments achieved a growth rate of $1.4 \%, 7.1 \%$, and $3.8 \%$ respectively accompanied by a public investment of $4.3 \%, 1.1 \%$, and $2.6 \%$. The coefficient of variation of the external gap was $-121.4 \%,-44.5 \%$ and $206.6 \%$ in that order. Despite the relatively high collection of indirect taxes and public investment during 1970 - 1985, the government achieved the lowest growth rate; the same is applicable to performance in the period 19902017 (Annex 1).

The detected structural breakpoints correspond to major events resembling the effects of famine in late 1983, the dismiss of thousands civil servants and military personnel as an opponents of the Ingaz regime in 1991, the highest ever hyperinflation in 1995; escalation of civil war 2003, and starting effects of separation of South Sudan in 2012 (annex 2).

The null hypothesis of no cointegrating equations is rejected according to the trace statistic (47.85) with Prob. 0.008. Thus, there are two cointegrating equations between real GDP, indirect taxes, external gap, unemployment rate and real effective exchange rate (annex 3 ).

The examination of integration properties of the model variables discloses that real GDP (Y) indirect tax ratio (ITR), unemployment rate (UR), and external gap (GAP2) are stationary at the first difference. Before involving in the estimation of the nonlinear model, we first test for the adequacy of the linear model through the application of BDS to the residuals of the fitted model. Results indicate the rejection of the null hypothesis at all six dimensions; therefore we use a non-linear threshold for estimation. 
Table (1) Estimated Model

\begin{tabular}{|c|c|c|c|c|}
\hline \multicolumn{5}{|c|}{ Dependent Variable: Y } \\
\hline \multicolumn{5}{|c|}{ Method: Discrete Threshold Regression } \\
\hline \multicolumn{5}{|c|}{ Date: $04 / 26 / 19$ Time: 02:07 } \\
\hline \multicolumn{5}{|c|}{ Sample (adjusted): 19702017} \\
\hline \multicolumn{5}{|c|}{ Included observations: 48 after adjustments } \\
\hline \multicolumn{5}{|c|}{ Selection: Trimming 0.15, , Sig. level 0.10} \\
\hline \multicolumn{5}{|c|}{ Threshold variable: ITR } \\
\hline \multicolumn{5}{|c|}{ Allow heterogeneous error distributions across breaks } \\
\hline Variable & Coefficient & Std. Error & T-Statistic & P-Value \\
\hline \multicolumn{5}{|c|}{ ITR $<3.263719--7$ obs. } \\
\hline ITR & 3530.131 & 1117.142 & 3.159965 & 0.003 \\
\hline Constant & 150526.9 & 21510.5 & 6.997833 & 0.000 \\
\hline \multicolumn{5}{|c|}{$3.263719 \leq$ ITR $<15$ obs. } \\
\hline ITR & 1652.526 & 693.4623 & 2.383008 & 0.0221 \\
\hline Constant & 147133.3 & 22868.08 & 6.434001 & 0.0000 \\
\hline \multicolumn{5}{|c|}{$7.45728 \leq$ ITR $<7.45728--26$ obs. } \\
\hline ITR & -3062.32 & 669.7784 & -4.57214 & 0.0000 \\
\hline Constant & 166242.1 & 24595.37 & 6.759081 & 0.0000 \\
\hline \multicolumn{5}{|c|}{ Non-Threshold Variables } \\
\hline GAP2 & -0.00027 & $5.77 \mathrm{E}-05$ & -4.68996 & 0.0000 \\
\hline UR & -10176.3 & 1597.89 & -6.36859 & 0.0000 \\
\hline REER & -25.195 & 10.21758 & -2.46585 & 0.0182 \\
\hline R-squared & 0.875335 & \multicolumn{2}{|c|}{ Mean dependent variable } & 14187.23 \\
\hline Adjusted R-squared & 0.849763 & \multicolumn{2}{|c|}{ S.D. dependent variable } & 9369.281 \\
\hline S.E. of regression & 3631.575 & \multicolumn{2}{|c|}{ Akaike info criterion } & 19.40008 \\
\hline Sum squared residual & $5.14 \mathrm{E}+08$ & \multicolumn{2}{|c|}{ Schwarz criterion } & 19.75093 \\
\hline Log-likelihood & -456.602 & \multicolumn{2}{|c|}{ Hannan-Quinn criteria. } & 19.53267 \\
\hline F-statistic & 34.22983 & \multicolumn{2}{|c|}{ Durbin-Watson } & 1.44943 \\
\hline P-Value (F-statistic) & 0.0000 & & & \\
\hline
\end{tabular}

The estimated model marks three regimes. The first two show the positive effect of indirect taxes on growth (Y) below the threshold. The third regime which is the negative effect occurs when indirect taxes pass the threshold. All estimated coefficients are statistically significant and explain $87 \%$ in the variation of Y. An increase in the external gap (GAP2) by one unit has a minor reduction in the real GDP by $0.0003 \%$, and other variable are held constant. An increase of $1 \%$ in unemployment rate drops the real GDP by 10176.3 Sudanese pounds in constant prices of 1981/82, and other variables remain constant. An increase of the real effective exchange rate by one unit cuts the real GDP by 25.2. Finally, if the ratio of indirect taxes increases by one, real GDP (Y) increases by 1652.526 below the threshold of $7.46 \%$ and decrease the GDP beyond the threshold by 3062.32. Sudanese pounds and other variable are held constant. According to Jarque-Bera statistic 5.82 with Prob. $=0.0 .54$, the model residuals are normally distributed. The model does not suffer from serial correlation and heteroscedasticity whereas Breusch- 
Pagan test for serial correlation LM and heteroscedasticity are P-Value $(\mathrm{F}(2,37)=0.26$; and $\mathrm{P}-$ Value $(\mathrm{F}(8,39)=82)$ respectively. The cumulative sum of squares test for stability reveals the constancy of the estimated coefficients as apparent in Figure (1) below.

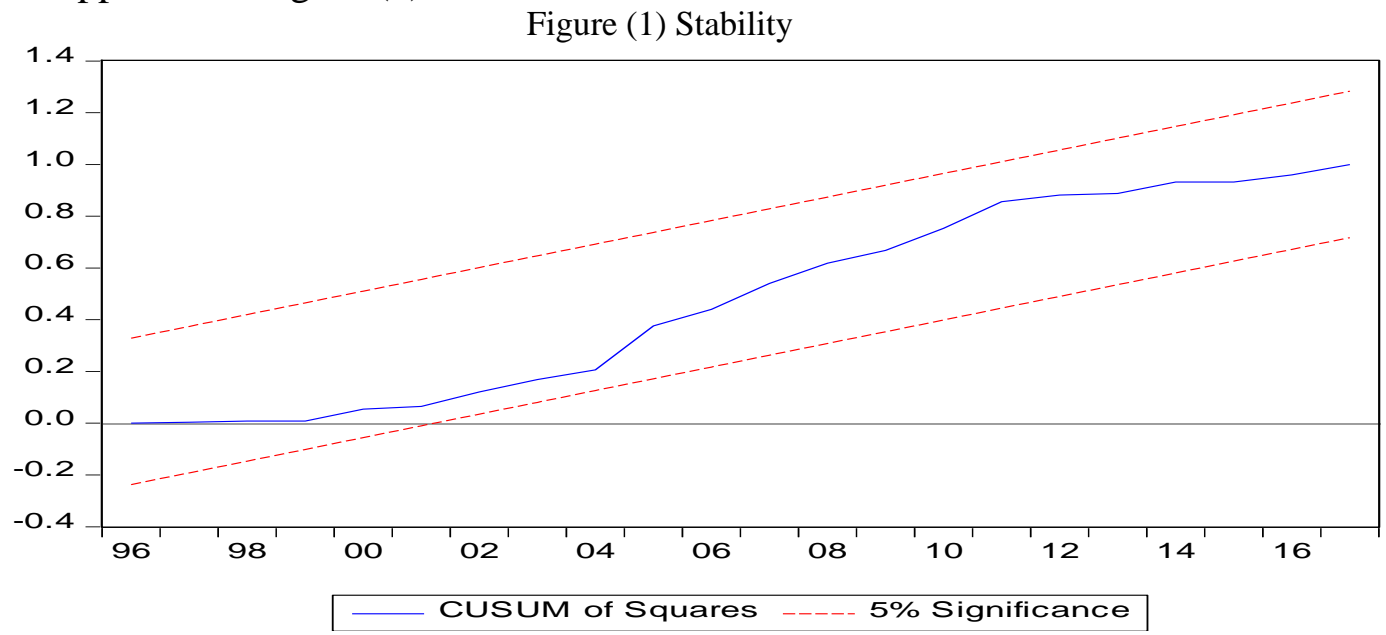

\subsection{Discussion}

The results tell that when indirect taxes cross a threshold of $7.46 \%$, they exert a negative impact on economic growth indicating the acceptance of the null hypothesis and confirming the work of Iloboya (2012) and Ahmed et.al. (2018). Indirect taxes represent the bulk of total government revenue contributing by $54 \%$, of which $68 \%$ comes from import duty. The main components of indirect taxes are sales taxes, excise duty, import and export duties, and value-added tax. Value-added tax is the most recent addition to the tax system. Empirical research found a negative relationship between direct taxes and economic growth, Sudan is not an exception since indirect taxes ratio correlate negatively to economic growth and has a significant correlation coefficient (-0.34). The model allows for heterogeneous error distribution, Durbin Watson and LM test indicate that the model is free of serial correlation between consecutive error terms.

The non-threshold variable external gap (GAP2) and the threshold indirect taxes ratio beyond the threshold show positive sign of magnitude 0.34 indicating the adverse impact on economic growth. This is justified by incorporation of a large amount of indirect taxes into these two variables. The external gap is the quotient of subtracting total import from total export. The first positive external saving was in the year 2000 as a consequence of exporting oil for the first time in the last quarter of 1999. The year 2004 witnessed the second positive external saving as a result of the surge in oil prices. It is worth mentioning that the cost of a barrel was 13 US dollars and it has to be paid to the consortium while the barrel price surged to 100 in 2004. 
Also, that year was the last one paying back the consortium the cost of oil exploration and construction of the pipeline. The year 2008 and 2010 showed a positive external saving as well due to the enlargement of oil extraction capacity. The external gap contains interest payments. The sustainability indicators of external debt which show the ability of the country to pay its debts are $30 \%, 100 \%$ and $200 \%$ external debt as a ratio of GDP, total exports and total revenue. However, the actual ratio of GDP is $40 \%$ and $45 \%$, and $1467 \%$ and $1323 \%$ of the total exports in 2016 and 2017, besides $472 \%$ and $409 \%$ of total revenue. Despite oil revenue, Sudan economy has not benefited as expected due to corruption and mismanagement of the economy. The external sector requires a lot of work in terms of policies and procedures. Foreign sector policies have frequently changed between self-sufficiency, tariffs, and fees on imports and export, additional fees to compensate subsidies, quota systems, control of the foreign exchange, administrative regulations, the public sector cater for import of basic needs, and joining custom unions (Arabi 2011).

The second non-threshold is the real effective exchange rate which measures the Sudanese pound to the basket of currencies of the trade partners. An increase in REER means that exports are expensive and import is cheaper which leads to the loss of competitiveness. REER showed global upward trend except in the year 1992 whereas the Sudanese pound was evaluated by more than $350 \%$ at once. The repercussion of the mutual effects of indirect taxes and the real effective exchange rate on real GDP is negative. An increase in the real effective exchange rate (REER) exerts a negative impact on real GDP by reducing competitiveness. The external gap has never displayed a positive sign throughout the sample period. The military government adopted socialist stances in the first two years of the 1970s, and then turned to capitalist through the consecutive twelve years. After then it enforced Islamic laws in the last two years of its span. The democratic government tracked different economic policies. The current government has been applying economic policies that benefit only its devotees. According to the Corruption Perception Index, the rank of Sudan has been descending from 106 out of 132 countries in 2003; 122 out of 141 in 2004 ; 144 out of 156 in 2005; to the fifth from the bottom in 2017 (Transparency International, 2017). The outcome of varying economic policies supplemented with weather conditions (desertification, and floods); civil war, displaced and refugee influx, and migration to urban areas. In addition, the split of South Sudan triggered a reduction in primary exports which constitute $90 \%$ and an increase in imports especially consumer goods and raw material.

The unemployment rate as well has a right negative sign, In addition, most private industries have been operating at very low capacity with obsolete technology that needs modernization, which in turn is hampered by the lack 
of foreign currency. Public investment crowds out private. Employment in the public sector depends mainly on nepotism and loyalty to the ruling party. More than 300,000 people not loyal to the ruling party have been fired during Numairi regime (1970 - 1985) and Ingaz regime (1989 - up to present). One adverse aspect of public investment is that it has been financed mainly by external debts which have accumulate to reach 47.1 billion dollars.

\section{Conclusion}

The principal objective of the research has been met by the application of a threshold regression (TAR) to the Sudanese data covering the period 1970 - 2017. The indirect tax ratio to GDP was the threshold variable while real exchange rate unemployment rate and external gap were the non-threshold variables. The choice of the model was based on BDS independence test. The estimated threshold regression determined indirect tax ratio to GDP of $7.46 \%$ as a maximum level that fosters the economic growth. This level corresponds to the base year 1982 (economically stable year) where all non-threshold variables are less than their average values. The application of the threshold regression model revealed that indirect taxes accelerate economic growth up to the threshold and have a negative impact beyond this threshold. It is recommended to diversify export, recapitalize the export and import bank (EXIM), revision of tariffs and fees, to sustain exchange rate policy. Accordingly, the research recommends restructuring the tax system to shift the balance in favor of direct taxes that curb price rises and attains social and economic balance, as well as reducing income inequality.

\section{References:}

1. Ahmad Shahzad, Sial Maqbool, H. \& Ahmed Nisar (2018). Pakistan Journal of Applied Economics, Vol.28 No.1, PP. 6581https://ideas.repec.org/s/pje/journl.html

2. Acemoglu Daron (2009). Introduction to Modern Economic Growth, Princeton NJPrinceton University Press https://press.princeton.edu/titles/8764.html

3. Arabi, Khalafalla Ahmed Mohamed (2011). Journal of Business Studies Quarterly Volume 2 Issue 2 PP. 41-53 https://www.google.com/search?q=Journal+of+Business+Studies+Qu arterly\&rlz=1C1CHBD_enSA833SA833\&oq=Journal+of+Business+ Studies+Quarterly\&aqs=chrome..69

4. Bai Jushan \& Perron Pierre (1998). Estimating and Testing Linear Models with Multiple Structural Changes: Econometrica, Vol. 66, No. 1 PP. 47-78Published by The Econometric Society http://www.jstor.org/stable/2998540. 
5. Bâzgan Mihaela (2018). The Impact of Direct and Indirect taxes on economic growth: An Empirical Analysis related to Romania https://www.researchgate.net/publication/325803628_The_impact_of _direct_and_indirect_taxes_on_economic_growth_An_empirical_ana lysis_related_to_Romania

6. Baum Anja \& Koester Gerrit, B. (2011). The Impact of Fiscal Policy on Economic Activity over the Business Cycle - Evidence from a Threshold VAR analysis Discussion Paper Series 1: Economic Studies No 03/2011 https://core.ac.uk/download/pdf/6670964.pdf

7. Boldeanu Florin Teodor \& Constantinescu Liliana (2015). The Main Determinants affecting Economic Growth Bulletin of the Transilvania University of Braşov Series V: Economic Sciences Volume. 8 (57) Issue No. http://webbut.unitbv.ro/BU2015/Series\%20V/BILETIN\%20I/38_Bol deanu\%20Constantinescu.pdf

8. Chong, Terence Tai Leung \& Yan Isabel, K. (2014). Estimating and Testing Threshold Regression Models with Multiple Threshold Variables muenchen.de/54732/1/MPRA_paper_54732.pdf https://mpra.ub.uni-

9. Chudik Alexander, Kamiar Mohaddes, G. \& Pesaran, M. H. (2015). Is There a Debt-threshold Effect on Output Growth? Federal Reserve Bank of Dallas Globalization and Monetary Policy Institute Working Paper No. $\quad 245 \quad$ IMF http://www.dallasfed.org/assets/documents/institute/wpapers/2015/02 45.pdf

10. Dagenais Marcel, G. (1969). A Threshold Regression Model Econometrica: Volume 37, Issue 2 https://www.econometricsociety.org/publications/econometrica/1969/ $\underline{04 / 01 / \text { threshold-regression-model }}$

11. Esen Omer \& Aydin Celil (2018). Optimal Tax Revenues and Economic Growth in Transition Economies: A Threshold Regression Approach. Global Business and Economics Review20(1): https://www.researchgate.net/publication/322215360_Optimal_Tax_ Revenues_and_Economic_Growth_in_Transition_Economies_A_Thr eshold_Regression_Approach

12. Gaspar Vitor, Jaramillo Laura \& Wingender Philippe (2016). Tax Capacity, and Growth: Is there a Tipping Point? IMF Working Paper $\mathrm{WP} / 16 / 234$ https://www.imf.org/external/pubs/ft/wp/2016/wp16234.pdf

13. Gibson David (2011). Threshold Auto regressive Models in Finance: A Comparative Approach University of Wollongong Australia 
https://ro.uow.edu.au/cgi/viewcontent.cgi?referer=https://www.googl e.com/\&httpsredir $=1 \&$ article $=1025 \&$ context=asearc

14. Heyman David (2011). Public Finance A Contemporary Application of Theory to Policy https://www.uv.mx/personal/clelanda/files/2014/09/Hyman-David2011-Public-Finance.pdf

15. Hunady Jan \& Orviska Marta (2015). The Non-Linear Effect of Corporate Taxes on Economic Growth Article in Timisoara Journal of Economics and Business https://www.researchgate.net/publication/273133905

16. Hurlin Christophe (2018). Chapter 3. Panel Threshold Regression Models, School of Economics and Management - University of Geneva https://www.univorleans.fr/deg/masters/ESA/CH/Geneve_Chapitre3.pdf

17. Ilaboya, O.J. \& Mgbame, C.O. (2012). Indirect Tax and Economic Growth, Research Journal of Finance and Accounting, volume 3, No. 11 www.iiste.org

18. Iyidogan Pelin Varol \& Turan Taner (2017). Government Size and Economic Growth in Turkey: A Threshold Regression Analysis. Prague Economic Papers, 2017, 26(2), 142-154, https://doi.org/10.18267/j.pep.600

19. Jaimovich Nir \& Rebelo Sergio (2015). Non-linear Effects of Taxation on

Growth https://www.kellogg.northwestern.edu/faculty/rebelo/htm/nonlinear.p df

20. Loganathan Nanthakumar, Ismail Suraya, Streamline Dalia, Hassan, Asan Ali Golam, Zavadskas, Edmundas Kazimieras \& Mardani Abbas (2017). Tax Reform, Inflation, Financial Development and Economic Growth in Malaysia. Romanian Journal Economic Forecasting-XX (4) PP 152 - 165 http://www.ipe.ro/rjef/rjef4_17/rjef4_2017p152-165.pdf

21. Mankiw Gregory, Weinzierl Matthew \& Yagan Danny (2007). Optimal Taxation in Theory and Practice https://scholar.harvard.edu/files/mankiw/files/optimal_taxation_in_th eory.pdf

22. Medani Ahmed, Rahmtalla Ali Baiker \& Bell Michael (2004). An Analysis of Fiscal Policies in Sudan: A Pro-Poor Perspective GWIPP Working Paper

Series https://gwipp.gwu.edu/sites/g/files/zaxdzs2181/f/downloads/Working _Paper_017_Sudan.pdf

23. Moraru Camelia \& Ioniţă Roxana (2014). The influence of Taxation on Economic Growth, Econometric Evidence from Romania. Management Strategies Journal Volume 26 issue 4 PP. 284-292 
https://econpapers.repec.org/article/brcjournl/v_3a26_3ay_3a2014_3 ai_3a4_3ap_3a284-290.htm

24. Pereiro Luis \& Rozada Martín González (2015). Forecasting Prices in Regime-Switching Markets.The Journal of Portfolio Management https://www.researchgate.net/publication/282467020

25. Phiri Andrew (2016). The Growth Trade-o_ Between Direct and Indirect Taxes in South Africa: Evidence from an STR model Munich Personal RePEc Archive https://mpra.ub.unimuenchen.de/69152/1/MPRA_paper_69152.pdf

26. Riba Lerato (2016). The Relationship between Tax and Economic Growth: A South African perspective Unpublished MSc. in Commerce in Development Finance University of Cape Town.

27. Rodrik Dani (2000). Institutions for High-quality Growth: What they are and How to Acquire them." Studies in Comparative International Development 35: 3-31.

28. Samimi Ahmad Jafari, Nademi Younes \& Zobeiri Hoda (2010). Tax Ratio Threshold and Economic Growth in Iran Australian Journal of Basic and Applied Sciences,https://www.academia.edu/11340833/Tax_Ratio_Threshold and_Economic_Growth_in_Iran

29. Saibu Olufemi Muibi (2015). Optimal Tax Rate and Economic Growth, Evidence from Nigeria and South Africa Euro Economica issue 34. https://www.researchgate.net/profile/Olufemi_Saibu

30. Stoilova Desislava \& Patonov Nikolay (2013). Empirical Evidence for the Impact of Taxation on Economy Growth in the European Union. Book of Proceedings-Tourism and Management Studies International Conference Algarve vol.3 https://www.researchgate.net/publication/276920184_An_Empirical_ Evidence_for_the_for_the_Impact_of_Taxation_on_Economy_Grow th_in_the_European_Union.

31. Transparency International (2017). Corruption Perceptions Index (CPI) https://www.transparency.org/news/feature/corruption_perceptions_i ndex_2017 
World Bank (2017). https://data.worldbank.org/

Annex (1) Descriptive Statistics

\begin{tabular}{|c|c|c|c|c|c|c|}
\hline Regimes & GR & REER & Real GDP & ITR & UR & GAP2 \\
\hline \multirow{4}{*}{$1970-1985$} & Mean & 129.31 & 6081.95 & 9.7 & 12.48 & -394.16 \\
\cline { 2 - 7 } & CV & 11.70 & 9.04 & 20.3 & 4.49 & -121.42 \\
\hline \multirow{3}{*}{$1986-1989$} & Mean & 170.05 & 7620.24 & 3.7 & 13.81 & -1716.3 \\
\cline { 2 - 7 } & CV & 27.20 & 8.74 & 37.6 & 1.30 & -44.75 \\
\hline \multirow{3}{*}{$2011-2017$} & Mean & 94.22 & 15874.51 & 6.5 & 2.01 & -1221154 \\
\cline { 2 - 7 } & CV & 69.78 & 36.97 & 4.3 & 13.46 & -348.92 \\
\hline & Mean & 107.24 & 43.86 & 9.3 & 0.95 & -79.81 \\
\hline & CV & 27.68 & 43.86 & 42 & 13.30 & -201.60 \\
\hline $1970-2017$ & Mean & 119.83 & 14187.23 & 4.9 & 3.38 & -6674533 \\
\cline { 2 - 7 } & CV & 43.66 & 6.04 & 27.6 & 82.65 & -201.6 \\
\hline
\end{tabular}

Annex (2) Unit Root with Break Test

\begin{tabular}{|l|c|c|c|c|}
\hline \multicolumn{3}{|c|}{ Augmented Dickey-Fuller } & \multicolumn{2}{c|}{ Break Date } \\
\hline & Intercept & Trend\& Intercept & Intercept & Trend\& Intercept \\
\hline $\mathrm{Y}$ & 0.053 & -1.1 & 2003 & 2002 \\
\hline$\Delta \mathrm{Y}$ & $-9.54^{* * *}$ & $-9.89^{* * *}$ & 1995 & 2004 \\
\hline ITR & -4.04 & $-5.48^{* *}$ & 1984 & 2002 \\
\hline UR & -3.17 & -2.53 & 2002 & 1997 \\
\hline$\Delta$ UR & $-16.73^{* * *}$ & $16.46^{* * *}$ & 1991 & 1991 \\
\hline GAP2 & -1.03 & -0.66 & 2012 & 2012 \\
\hline$\Delta$ GAP2 & $5.86^{* * *}$ & 0.66 & 2014 & 2012 \\
\hline REER & $-5.78^{* * *}$ & $-11.67^{* * *}$ & 1991 & 1991 \\
\hline
\end{tabular}

Annex (3) Cointegration Test

\begin{tabular}{|c|c|c|c|c|}
\hline \multicolumn{5}{|c|}{ Date: $04 / 26 / 19$ Time: $13: 50$} \\
\hline \multicolumn{5}{|c|}{ Sample: 19702017} \\
\hline \multicolumn{5}{|c|}{ Included observations: 48} \\
\hline \multicolumn{5}{|c|}{ Trend assumption: Linear deterministic trend } \\
\hline \multicolumn{5}{|c|}{ Series: Y GAP2 REER ITR UR } \\
\hline \multicolumn{5}{|c|}{ Lags interval (in first differences): 1 to 1} \\
\hline \multicolumn{5}{|c|}{ Unrestricted Cointegration Rank Test (Trace) } \\
\hline \multicolumn{2}{|c|}{ Hypothesized } & Trace & 0.05 & \\
\hline No. of $\mathrm{CE}(\mathrm{s})$ & Eigenvalue & Statistic & Critical Value & Prob.** \\
\hline None * & 0.550276 & 93.9126 & 69.81889 & 0.0002 \\
\hline At most $1 *$ & 0.416812 & 55.55473 & 47.85613 & 0.008 \\
\hline At most 2 & 0.343424 & 29.67091 & 29.79707 & 0.0517 \\
\hline At most 3 & 0.17497 & 9.476527 & 15.49471 & 0.3231 \\
\hline At most 4 & 0.00508 & 0.244446 & 3.841466 & 0.621 \\
\hline \multicolumn{5}{|c|}{ Trace test indicates 2 cointegrating eqn(s) at the 0.05 level } \\
\hline \multicolumn{5}{|c|}{$*$ denotes rejection of the hypothesis at the 0.05 level } \\
\hline \multicolumn{5}{|c|}{ **MacKinnon-Haug-Michelis (1999) p-values } \\
\hline
\end{tabular}


Annex (4) Breusch-Godfrey Serial Correlation LM Test

\begin{tabular}{|c|r|c|r|}
\hline F-statistic & 1.432435 & Prob. F(2,37) & 0.2517 \\
\hline Obs*R-squared & 3.449498 & Prob. Chi-Square(2) & 0.1782 \\
\hline
\end{tabular}

Annex (5) Heteroskedasticity Test: Breusch-Pagan-Godfrey

\begin{tabular}{|c|r|c|c|}
\hline F-statistic & 0.538266 & Prob. F $(8,39)$ & 0.8204 \\
\hline Obs*R-squared & 4.772864 & Prob. Chi-Square $(8)$ & 0.7816 \\
\hline Scaled explained SS & 4.258216 & Prob. Chi-Square(8) & 0.8331 \\
\hline
\end{tabular}

